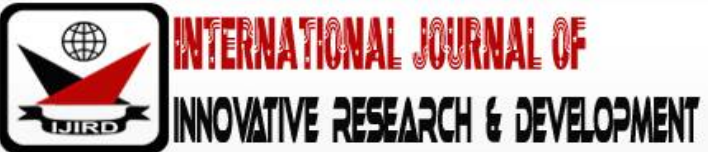

ISSN 2278-0211 (Online)

\section{An In-Depth Analysis of Nigerian Preliminary Offences: Inchoate Crimes}

\author{
Bello Usman Aliyu \\ Ph.D. Candidate, Department of International law, Near East University, Cyprus
}

\begin{abstract}
:
This work will analyze inchoate crimes under the Nigerian Law, the Nigerian status prohibiting these crimes are the Penal and the Criminal Codes Laws of Northern and Southern Nigeria respectively. Inchoate crimes represent such offences that are considered actionable and the law enforcement agencies are permitted by the law to intervene and stop the perpetrators on their track before realizing their criminal intentions. The work will attempt to review the problems of this aspect of the Law, which include difficulty of ascertaining the level to which parties to a crime participate in the commission of offences such as Conspiracy or Abetment. The objectives of this work would be achieved through doctrinal and empirical methods of research, recommendations would also be made for further research on this aspect of the law so that the area can be developed for contribution to the development of knowledge generally and criminal law in particular.
\end{abstract}

Keywords: Criminal law, difficulty of ascertainment, inchoate crimes, Nigerian preventive law, parties participation in crimes, statutes

\section{Literature Review}

No Nigerian writer has worked on an article purely on this subject, except as a topic or a chapter among many chapters in a text book within the general scope of criminal law. An obvious reason is that, in substance, it appears simple and straight forward particularly given the various provisions of both the Criminal and the Penal Codes on the subject. However, as this work will show, the subject is anything but simple.

Writers who treated this subject in their works include Chukkol, K.S., Okonkwo, C.O., Aguda, T., and Okagbue, Isabella, and Ocheme, P., in their books, The Law of Crimes in Nigeria, Okonkwo and Naish Criminal Law in Nigeria, The Principles of Criminal liability in Nigeria and the Nigerian Criminal Law, respectively, the learned authors discussed the nature and scope of inchoate crimes, however the subject was just discussed as a topic under a chapter in their various works.

Chukkol, K.S. discussed the various forms of crimes that make up the bulk of inchoate crimes separately, the learned author discussed the offences of conspiracy, abatement, and attempt, with available defenses thereto. This work will review some of his submissions and critically analyse them in line with the general concepts of Conspiracy, Incitement/Complicity and abatement together with the defenses thereof.

Ocheme, P. in his work opines that, it is the objective of the criminal justice system to punish not only those who commit crimes, but also those whose criminal tendencies are apparently dreadful, thence inchoate crimes. He however argued against this philosophy, where he maintains that it is equally the rule of law that mischievous intention, wickedness, hatred, or malicious mindedness without any actus-reus (physical act), no matter how gravely held in mind, are not criminal behaviors. This may be correct of inchoate crimes speaking generally, however there are situations where the law may hold persons liable for just making preparations towards the commission of an offence. These stages include for instance preparatory stages to produce fake currency notes, making materials that can be used as explosives, committing treason and incitement to riot or mutiny. In these mentioned offences the absence of actus reus (physical act) will not prevent the law from intervening in order to prevent the final commission of the crime.

By this argument the criminal law has no business in encouraging kindness or the upholding of moral virtues. In a much similar way, criminal acts cannot make a person guilty of an offence without the necessary criminal intention (mens reus). Even in such preparatory circumstances, the main criminal elements mentioned earlier must be proved to have existed before a conviction can be secured, i.e., a premeditated criminal intention backed by the commission of an offence pointing to that intention. This work will benefit from the analysis on the topic by these eminent authors, but it will be more elaborate in its review.

Smith and Hogan discussed preliminary offences under the English law, where like their counter parts in Nigeria define all the stages involved before the commission of inchoate crimes. The learned authors discussed in details the offences of conspiracy, incitement and abatement. The learned authors submitted that before the commission of a crime 
there must be an intention to commit the act, preparations towards the commission of the act, and lastly the actual commission of the criminal act.

Richardson, S.S. made an in-depth commentary on the provisions of the Penal Code Laws of Northern Nigeria, where he discussed in details the various provisions of the Code (including sections of that code relating to inchoate crimes). His work though not strictly on the subject of this work is however found to be very much helpful and will be consulted.

\section{Statement of the Problem}

The main purpose of this work is the appraisal of inchoate crimes (Preliminary offences) under the Nigerian law so as to put in perspective the nature, and ingredients of such offences and their role among repressive Laws. Very often, crimes are committed by more than one person and the questions that always arise in these circumstances are to what extent can each party be held liable for the criminal act, what is their level of participation?, at what stage in the plan to commit the criminal act can a crime be said to have been committed?, was any of the parties heaving a different intention from the others or were both of them harboring a common intention?.

When different persons having a common intention to commit a crime succeed in the pursuit of that intention, example by planning to go and rob a bank, one of them may provide a gun, the other provides an escape vehicle, and another may also have provided information. Both of them may be found liable for the crime of armed robbery. If A and B enters into a female dormitory with the intention of raping a female student, and the security man promises to warn them in the event of an unexpected intrusion, both of them including the security man will be liable for the same offence. The security man here needs not to do anything further in the committing of the said rape but he will have the same liability with the duo if his intention can be proved.

Similarly, where an agreement among deferent persons for the commission of a crime (e.g. agreeing to produce fake currency bank notes by them) is reached failure to succeed in committing the crime cannot be used as a defense against liability.

The difficulty encountered in these crimes by judges and Lawyers are the issues of legal and factual impossibility of performance. Can persons be liable for the crimes of attempt, conspiracy, incitement, or abetting the commission of a crime that is impossible to commit, or an act not deemed criminal in law? These and many other related questions shall be explored and their answers searched for by this work.

The law is in precise in determining what amount to a common purpose among offenders and this work will attempt to explore that area and provide a solution so that what amounts to an attempt as it relates to the common purpose of the offenders can be clearly defined and this would help in ascertaining what preliminary steps could amount to a conspiracy or an attempt.

\subsection{Methodology}

\subsubsection{Research Philosophy}

The research philosophy of this work will be premised on the fact that Law, from the Lawyers' point of view trained on a finer point of English law, is in a written form. This written law may be in the form of enacted, statutory or other auxiliary legislations, this is more so with regard to criminal acts. To this end the work will be analytical, in that it will analyse and review the various works of some experts and scholars in this aspect of the law.

\subsubsection{Research Design}

In this regard the research methodology of this work will be both doctrinal and empirical. The doctrinal method will entail consulting primary sources of law, (for example) penal laws in Nigeria on this aspect of the research. Equally, the opinion of some legal writers, and scholars, expressed in text books, works, periodicals, Newspapers, and magazines on inchoate offences will be consulted. The empirical method of the research will entail consulting such secondary sources of law. The law library will therefore serve as a useful place where the doctrinal and empirical method of this research will be conducted. This means that the bulk of this research will be done in the Law Library.

However, where necessary, one on one discussion with scholars and lawyers knowledgeable in the area of this research will be resorted to, in order to clarify some knotty points.

The writer will exhibit originality (where necessary) in making recommendations that will improve the topic of this research

\section{Objectives of the Study}

The objectives intended to be achieved by this work are as follows: -

- To make an in-depth research into the various preliminary offences and other conducts that amount to "inchoate offences", by stating the current position of the law.

- To highlight in details the nature, scope and frame work of the various forms of inchoate offences.

- To examine the ingredients of the various forms of inchoate offences in order to help in understanding the concepts in general, together with the constituents that make it up specifically.

\section{Scope of the Study}

The scope of this work will be limited to the analysis of preliminary offences, under Nigerian Law. These offences are prohibited by statutes, i.e. the Penal and the Criminal Code. Analysis in this work will be limited to the relevant 
provisions of these Codes which are the main penal legislations in Nigeria. Reference, however, will be made to the penal legislation of other countries, where appropriate.

\section{Justification for the Study}

The justification for the study of inchoate crimes can best be appreciated if one looks at the statement of the problem and the objectives of this work. No crime can be proved without establishing its main constituents, intention and the level of participation by each of the accused persons (if more than one) or the extent of execution of the planned crime.

\section{Significance of the Study}

The subject matter of this work appears imperative in the present-day Nigeria, considering the various security challenges we are facing and the level of sophistication, organization, multiplicity of the perpetrators and the need for repressive Law to intervene at the earliest possible time so as to detect and apprehend any person or group of persons involved in any criminal enterprise.

The work will be much useful to Lawyers, Judges, Academicians, Law students and of course the various law enforcement agencies saddled with the responsibility of preventing crimes and the general protection of the society at large.

The study will also serve as a fillip to the existing literature in Nigeria on the topic, in that it will help to boost the understanding and appreciating the nature and scope of this aspect of criminal law and the rationale behind the position of the law on such crimes.

\subsection{Introduction}

The main goals and objectives of the law and criminal law in particular is the protection of the public from conducts that are harmful by meting punishment not only against persons who have committed acts that are injurious to others but also those whose actions are geared towards committing the harmful acts. The acts that criminal law prevents differs, it may be harmful acts that can result to death, physical or bodily injury, properties' loss or damages, sexual promiscuity, threat to government's existence, and public peace disturbances.

Acts likely to, but have not yet caused, harmful results will be enough to be considered as crimes. Thus, law tries to prevent harm by proscribing acts which can lead to injurious results. Criminal liability therefore applies not only to persons who commits injurious acts but also to those whose aids and assistance are vital in the commission of such acts.

A person who begins to manifest his injurious intension can be liable for an offence before he ever achieves his aim . Thus, inchoate crimes, which are also referred to as incomplete crimes, have been defined as conduct deemed criminal without actual harm being done, provided that the harm that would have occurred is the one the law tries to prevent. The reason for designating these crimes is to prevent them from happening. The most important of these preliminary offences under the Nigerian law are attempt and conspiracy.

\subsection{Meaning of Inchoate Crimes}

The literal meaning of the word inchoate is just beginning to form and therefore not clear or developed. Accordingly, inchoate crimes can be defined as imperfect offences or steps towards the commission of an offence. Put in a different way, inchoate crimes are offences resulting from preparedness to commit harmful acts. Inchoate crimes could also be defined as conducts deemed criminal without actual harm being done, provided that the harm that would have occurred is one which the law tries to prevent.

Similarly, the Black's law dictionary has defined inchoate crimes as steps toward the commission of another crime, the step in itself being serious enough to merit punishment. There are three inchoate crimes under the Nigerian criminal law, i.e., attempt, incitement/abetment/solicitation, and conspiracy.

However, the term inchoate crime remains a subject of criticisms and these criticisms are not only appealing but persuasive and that may be the likely reasons why the term is not being used frequently under the Nigeria law. I in the light of this, I submit that a fully completed offence should be distinguished from preparatory steps towards the commission of an injurious act, because the two can be initiated and performed independent of each other, and the performance of one does not necessarily result in the commission of the other. It is equally my submission with all due respect, that the term 'inchoate crimes' is inappropriate and that the correct term should have been 'preliminary crimes'.

In my humble opinion, those act that happen preceding to and preparatory to what may be a subsequent crime are referred to as inchoate crimes. Inchoate crimes therefore, consist of attempting, conspiring, inciting, or soliciting to commit some criminal acts. An inchoate crime is a completed crime in itself, even though a further contemplated criminal act has not been completed. When two or more persons for example, agree among themselves to attack and kill another, they will be liable for the crime of conspiracy whether they succeed in carrying out their act or not.

\subsection{Forms of Inchoate (Preliminary) Crimes}

\subsubsection{Incitement}

Both the Criminal and Penal Codes did not give a precise definition of an act referred to as Incitement, but it seems that incitement as a preliminary offence is the same with the inchoate crime of abetment. Inciting another to commit an indictable act is a misdemeanor under the common law and, it matters not that the person incited is persuaded successfully to commit, or attempt to commit the crime. Incitement or abetment happens when a person directs, encourages or instructs another to commit a criminal act. An example here is the crime of prostitution. The offence is 
completed when one person instructs, or encourages another to commit a prohibited act. The offences of solicitation or incitement have two main ingredients:

- Intention to have the crime committed by someone else.

- The other person is induced by an act of the other.

A person must have a specific intention of trying to induce another for the act of committing a crime before he can be liable for the offence of solicitation, such intention could be adduced from his usage of some key words, or phrases peculiar to the crime. However, he cannot be charged with both solicitation and the actual crime committed, thus the offences of solicitation and/or incitement will be merged together with the completed offences and prosecuted.

\subsubsection{Abetment}

Another form of inchoate crime is abetment, and the crime is said to have been committed when a person encourages or incites another to commit another crime. Words or phrases need not to be uttered in some situations, even signs and gestures might be sufficient. Words used in incitement must not be direct. As it was held in the Indian case of Emp. V Nazir Ahmad, that a by stander had abetted the Landlord in committing an offence of assault when the Land Lord assaulted a tenant for not paying rent and an unruly behavior while the by stander was encouraging him to take more drastic actions against "the tenants of now a days".

It will not be a defense to argue that the offence to be committed was for any other reason not committed at the end, for example it is not a defense to a High school Principal that an act he abetted was not committed, when he gave student instructions to break, enter and remove from a boutique some jewelry. However, both of them were not aware that fire has destroyed the boutique the preceding nights and the goods burnt. At midnight the student showed up with house breaking tools for the operation and was subsequently arrested at the scene, he later made confessions for his mission. In this case the Principal was liable for abetting the offence, notwithstanding the fact that it would not have been possible for the student to commit the offence abetted.

Section (87) of the penal code provides that a person abetting a crime may be liable even when the other person commits another offence different from the abetted one if it can be proved that the subsequent offence is a likely consequence from the abetted one. If a person abets another to commit robbery at a bank, and supplies him with a gun, during the operation the Bank cashier was killed. In this case the person abetting the robbery will be liable as an abettor of both the crimes of robbery and murder.

\subsubsection{Attempt}

The most important category of inchoate offence is attempt, which consists of any conduct intended to accomplish a criminal result that fails of consummation but goes beyond acts of preparation to a point dangerously, close to completion of the intended harm. The line between acts of mere preparation and attempt is difficult to draw in many cases. Trying to commit an offence and failing is an attempt, and it is often referred to as the most penal crime (inchoate crime) because the crime may have become close to completion. In this regards a person would be charged with attempted murder when shoots but misses to kill another, if such intention can be proved, however he would have been charged with murder If he has succeeded in killing the victim.

Therefore, it is an offence to attempt to commit any offence. In some crimes, law specifies the punishments to be meted for an attempt such as life imprisonment under section (320) of the criminal code for attempted murder.

The objective of Criminal law here is to prevent the committing of offences, as it is popularly said, "to nib the accused person's diabolical plans in the bud". The provision of section (4) of the Criminal Code reads:

When a person, intending to commit an offence, begins to put his intention into execution by means adapted to its fulfillment and manifests his intension by some overt act but does not fulfill his intention to such an extent as to commit the offence he is said to attempt to commit the offence.

A person must have undergone the following stages before he could have committed the forbidden act:

- Firstly, he must have had the intent to commit such an offence, and he would then have embarked on some preparatory moves in pursuance of committing the offence, and lastly, he would have had the crime actually committed.

- It must also be proved by the prosecution that the accused has had the intention of committing the crime which he was alleged to have attempted committing. The accused in R V. Offiong, entered the room of a woman uninvited, took off his clothes, expressed to her his desire for sexual intercourse, even caught hold of her body. It was held by the court that these acts were not sufficiently enough for an attempted rape. There was no evidence suggesting that the accused had the intention of forcefully having a sexual intercourse with the woman against her wish, and as such, his actions could not have amounted to attempted rape because intention to have the intercourse without the woman's consent must be proved to be in existence in rape as explained by Section (357) of the criminal Code.

\subsubsection{Conspiracy}

Under Nigerian Law, two or more persons who entered into agreement for the purpose of accomplishing an unlawful act or accomplishing a lawful act by unlawful means are guilty of conspiracy.

There must be more than one person for the offence of conspiracy to be committed, because a conspiracy results from an agreement and one person cannot make an agreement. In a situation for instance, where the prosecution charge only two persons with conspiracy, it is a general rule that where one is acquitted then the other accomplice too must be set free. Equally, conspiracy is a separate crime from the main offence and as such the two do not merge. Hence, the persons 
must be charged individually and separately for committing the offence which is actually committed, and each of the crimes will be punished separately

It is a trite law that as long as a person's intention to commit an offence remains in him alone, there will be no interference from the criminal law. But when several persons form a common intention to commit an offence, then criminal law will intervene to stop them from achieving their mischievous intention, and then charge them with the offence of conspiracy. The combine effect of sections (516) and (517) of the penal Code is to render persons who agree among themselves to commit a forbidden act liable to punishment

\section{Recommendations}

The main bulk of this work discussed and reviewed what is regarded as the criminal content of an endeavor to commit an offence, or a forbidden preparation for the commission of a particular crime.

However, it is argued that it is the rule of law that mischievous intention, wickedness, hatred or malicious mindedness without any actus-reus (physical act), no matter how gravely held in the mind are not criminal behaviors.

In line with what was previously discussed, the following recommendations are hereby proposed: -

Section (34) of the Criminal Code which regards husband and wife of a Christian marriage as one for the purpose of the offence of conspiracy should equally apply to polygamous marriages. It is therefore recommended that a similar section be enacted under the Penal Code. In this regard the Tanzanian case or R Vs. Manji where the privacy council held that the doctrine of unity of spouses applies to polygamous marriages becomes a guiding principle.

Similarly, it is my recommendation that criminal attempt under section (95) of the Penal Code needs to be redrafted, the section provides thus:

Whoever attempts to commit an offence and, in such attempt, does any act towards the commission of the offence shall be punished with imprisonment.

The provision begins with "whoever attempts", the question that arises is, what is then an attempt? Because by beginning with the phrase "whoever attempts" the provision did not give any meaning of attempt compared with its Criminal Code counterpart which provides thus:

When a person, intending to commit an offence, begins to put his intention into execution by means adapted for its fulfillment and manifests his intention by some overt act but does not fulfill his intention to such extend as to commit the offence he is said to attempt to commit the offence.

It is therefore my opinion that the provision of the Criminal Code above is much better framed and meaningful than the provision of the Penal Code, hence Section (95) of the Penal Code needs to be redrafted to give it a better and meaningful definition of the crime of attempt.

It is my suggestion that, other writers should endeavor to make further research on this aspect of the law so that the area can be fully developed, and other loopholes within the criminal justice system can be checked.

\section{Conclusion}

Inchoate crimes are conducts deemed criminal without actual harm being done, provided that the harm that would have occurred is one that is forbidden by a statute.

Thus, this work examined the offences by appraising the relevant provisions of our Codes. The offences are justified in that inchoate crimes enable law enforcement agencies to intervene at the earliest time. To curb the consequences of criminal enterprise of two or more people as soon as they have reached an agreement is a better strategy for the protection of the society from the evil consequences that would have ensued if such evil enterprise is pursued by such group. To stop a person who had started to put his evil plans into action by meting out to him some punishment is deterrence enough since otherwise such person would have tried again to achieve his criminal intent. And finally, those who agreed to be used by another person who commissioned them for a Criminal purpose should know that there is no escape route for them to argue that the original mens rea (state of the mind) is that of another with regard to the crime abetted.

Finally, it is hoped that the few recommendations made in this work will help in the development of this area under Nigerian criminal law.

\section{References}

i. Aguda, T.A. (1971) Selected Lectures and Papers (Ibadan, Nigeria)

ii. Christine L. (1809) Williams Blackstone's Commentaries on the Laws of England (15th Edition) Oxford Press, London

iii. Chukkol, K.S. (2010) Law of Crimes in Nigeria (Revised Edition) Zaria, Nigeria. Ahmadu Bello University Press Limited

iv. Denning, L.J. (1945) the Changing Law. Queens Press, London

v. Deviling, P. (1959) the Enforcement of Morals. Oxford Press Limited

vi. Encyclopedia Britannica (1977) Students and home Edition. Oxford Press Limited

vii. Garner, B.A. (1999) Black's Law Dictionary (11th Edition) West Group Publishing Cooperation

viii. Hall and Jerome (1960) General Principles of Criminal Law (2nd Edition) London Stephens Publications

ix. Hart, H. L. (1963) Law and Morality. Oxford Press Limited

x. Hamby, A.S. (2005) Oxford Advanced Learners Dictionary of Current English (7th Edition) London Oxford University Press

xi. Jefferson, M. (2003) Criminal Law (6th Edition) England Pearson Longman 
xii. John, A. (1920) "Lecture on Jurisprudence" Lecture No. 27 Students Edition.

xiii. Mills, J. S. (1859) Essays on Liberty. Queens Press London

xiv. Ocheme, P. S. (2010) The Nigerian Criminal Law (1st Edition) Kaduna Nigeria Ahmadu Bello University Press Limited

xv. Okonkwo, C.O. (1980) Criminal Law in Nigeria. (Revised Edition) Ibadan, Nigeria. Spectrum Publishers

xvi. Pound, R. (1964) Interpretation of Legal History. Harvard University Press

xvii. Smith \& Hogan (1978) Criminal Law (11th Edition) London, Publishers Limited

xviii. Williams, G. Text Book of Criminal Law (3rd Edition) London.

xix. www.lawyers.com.criminalliability. Visited on 19th Oct. (2019)

xx. Http//en.wikipedia.org/wiki/inchoate offence. Visited on 19th Oct.(2019)

xxi. www.lawyers\&inchoateoffences.com. Visited on 21st Oct. (2019)

xxii. Http//en.wikipedia.org/wiki.impossibility.offence. Visited on the 20th Oct. (2019) 